\title{
PReS13-SPK-1321: Expanding clinical spectrum of autoinflammatory diseases
}

\author{
I Aksentijevich \\ From 20th Pediatric Rheumatology European Society (PReS) Congress \\ Ljubljana, Slovenia. 25-29 September 2013
}

The term autoinflammation was initially introduced to denote a group of diseases that lacked the usual features of autoimmunity (high-titer autoantibodies and antigenspecific $\mathrm{T}$ cells), and were subsequently recognized as disorders of the innate immune system. Patients with autoinflammatory disorders present with chronic and recurrent bouts of systemic inflammation that are mediated by the cells of the innate immune system such as neutrophils and macrophages. The concept of autoinflammation started with hereditary recurrent fevers, but has grown substantially to include both monogenic and polygenic diseases. Hereditary recurrent fevers are the prototypic monogenic disorders, whereas Behçet disease, Crohn disease, gout, spondyloarthropathies, type-2 diabetes are all considered complex autoinflammatory diseases. The monogenic autoinflammatory diseases are inherited in an autosomal-recessive or autosomaldominant fashion, and many of disease-causing mutations are found in genes that regulate the IL-1 signaling pathway. More recently, new pathways such as the IL-36, immunoproteasome, HOIL-1 deficiency, and phospholipase $\mathrm{C} \gamma 2$ pathways have been identified in the pathogenesis of autoinflammation. Some of these new autoinflammatory diseases and relevant pathways will be discussed at the meeting. Despite major advances, a substantial number of patients have no mutations in the known autoinflammatory genes. The present challenge is how to find the as-yet undiscovered genes, considering that most cases are sporadic or occur in small families that are not suit-able for linkage analysis. New approaches and tools such as next-generation sequencing are the most likely methods to be successful. Such research might require collabora-tive studies in order to increase the number of patients presenting with a rare phenotype.

Inflammatory Disease Section, National Human Genome Research Institute, Bethesda, USA
Submit your next manuscript to BioMed Central and take full advantage of:

- Convenient online submission

- Thorough peer review

- No space constraints or color figure charges

- Immediate publication on acceptance

- Inclusion in PubMed, CAS, Scopus and Google Scholar

- Research which is freely available for redistribution Submit your manuscript at
www.biomedcentral.com/submit C BioMed Central 